\title{
Snowdrift modelling for the Vestfonna ice cap, north-eastern Svalbard
}

\author{
T. Sauter ${ }^{1,2}$, M. Möller ${ }^{2}$, R. Finkelnburg ${ }^{3}$, M. Grabiec ${ }^{4}$, D. Scherer ${ }^{3}$, and C. Schneider ${ }^{2}$ \\ ${ }^{1}$ Institute of Meteorology and Geophysics, University of Innsbruck, Austria \\ ${ }^{2}$ Department of Geography, RWTH Aachen University, Germany \\ ${ }^{3}$ Department of Ecology, Technische Universität Berlin, Germany \\ ${ }^{4}$ Department of Geomorphology, University of Silesia, Poland
}

Correspondence to: T. Sauter (tobias.sauter@geo.rwth-aachen.de)

Received: 5 February 2013 - Published in The Cryosphere Discuss.: 28 February 2013

Revised: 29 May 2013 - Accepted: 28 June 2013 - Published: 12 August 2013

\begin{abstract}
The redistribution of snow by drifting and blowing snow frequently leads to an inhomogeneous snow mass distribution on larger ice caps. Together with the thermodynamic impact of drifting snow sublimation on the lower atmospheric boundary layer, these processes affect the glacier surface mass balance. This study provides a first quantification of snowdrift and sublimation of blowing and drifting snow on the Vestfonna ice cap (Svalbard) by using the specifically designed snow2blow snowdrift model. The model is forced by atmospheric fields from the Polar Weather Research and Forecasting model and resolves processes on a spatial resolution of $250 \mathrm{~m}$. The model is applied to the Vestfonna ice cap for the accumulation period 2008/2009. Comparison with radio-echo soundings and snow-pit measurements show that important local-scale processes are resolved by the model and the overall snow accumulation pattern is reproduced. The findings indicate that there is a significant redistribution of snow mass from the interior of the ice cap to the surrounding areas and ice slopes. Drifting snow sublimation of suspended snow is found to be stronger during spring. It is concluded that the redistribution process is strong enough to have a significant impact on glacier mass balance.
\end{abstract}

\section{Introduction}

In high Arctic regions, redistribution of snow mass by wind drift has an important impact on the mass balance of glaciers. The intensity of the redistribution process is essentially given by the interaction of the inherent erosional capacity of the wind flow and the snowpack characteristics. Particularly along the margin of larger ice caps, persistent katabatic winds become often strong enough to effectively remove snow from the surface and re-accumulate the eroded snow mass within the surrounding areas (e.g. Boon et al., 2010; Mernild et al., 2006). Once snow particles become mobile, they can be advected over long distances by the mean flow, while influencing the turbulent structure of the atmospheric boundary layer. Snow particles that are entrained far upwards (above $2 \mathrm{~m}$ ) by turbulent eddies are generally referred to as blowing snow, whereas the advection of snow mass within the surface layer is referred as drifting snow. During transport, part of the snow mass is removed by sublimation, which modifies the vertical temperature and moisture profiles of the nearsurface layer. The cooler and more humid air masses then have a non-neglectable impact on the surface energy fluxes. Since the effect on mass balance can be strong, bridging the gap between drifting and blowing snow and the local-scale impact on glacier mass balance in polar regions has been addressed by several glaciological studies (e.g. Jaedicke, 2002; Bintanja, 1998; Lenaerts et al., 2010, 2012).

The importance of drifting and blowing snow in the European Arctic has early been postulated by Ahlmann (1933). Based on point field measurements in Nordaustlandet, he estimated that at least $1 / 8$ of the total snow accumulation is redistributed by wind. The first detailed accumulation map of Nordaustlandet (Svalbard) has been provided by Schytt (1964), based on point measurements collected during the Swedish glaciological expedition in 1957/58. Later, better insights along several transects have been gained by extensive 
repeated ground penetrating radar measurements carried out by Taurisano et al. (2007) and Grabiec et al. (2011). Both studies substantially contributed to a better understanding and a consistent idea of the spatial snow cover pattern on the two large ice caps on Nordaustlandet, Austfonna and Vestfonna. Their findings have been recently affirmed by on-site snow measurements from Möller et al. (2011b) and Beaudon et al. (2011). Unfortunately, due to the heterogeneity of the complex snowdrift processes a comprehensive, glacier wide spatio-temporal quantification by measurements prove to be a challenging task.

This study presents the first spatio-temporal estimate of snowdrift in the south-west part of the Vestfonna ice cap. We discuss the processes involved and describe the mathematical framework of the specifically designed three-dimensional snow2blow model. The model is then applied to the Vestfonna ice cap for the accumulation period 2008/2009. Model results are compared with radio-echo sounding measurements and on-site snow-pit data. Finally, the contribution and influence of individual components on the snow distribution is discussed in detail.

\section{Study area}

The ice cap Vestfonna covered a surface area of $2340 \mathrm{~km}^{2}$ in 2005 (Braun et al., 2011) and is thus the second largest single ice mass of the Svalbard archipelago and among the largest ice caps of the Eurasian Arctic (see Fig. 1). Its starshaped ice dome is formed by an east-west oriented ridge that extends over the main summit, Ahlmann. From the eastern summit, which is the highest point of the ice cap $(647 \mathrm{~m}$ over WGS84 (World Geodetic System 1984) ellipsoid; Braun et al., 2011), a secondary ridge extends towards the north. Apart from these main ridges the morphology of Vestfonna is dominated by several land-terminating ice lobes and extensive outlet glacier basins that form marine-terminating, calving glacier fronts.

The strongly maritime climate of Svalbard is characterized by the contrasting influences of warm and humid North Atlantic air masses to the south and cold and dry Arctic air masses to the north-east (Svendsen et al., 2002). The warm West Spitsbergen Current (Walczowski and Piechura, 2011) frequently causes sea-ice free conditions along the western part of the archipelago while the eastern areas are directly influenced by cold Arctic Ocean currents (Loeng, 1991) with closed sea-ice cover during most winters. Extratropical cyclones mainly control the synoptic-scale variability in the southern parts of the archipelago while the Arctic high pressure system forms the strongest influencing factor for the northern parts (Skeie, 2000). The synoptic forcing markedly imprints on the surface climate especially during the winter months (Bednorz and Fortuniak, 2011). The synoptic-scale airflow across the archipelago is dominated by southerly directions during the summer season while during winter north-easterly directions prevail (Käsmacher and Schneider, 2011).

Due to its location within the archipelago, Nordaustlandet is less directly influenced by the warmer Atlantic air and water masses. Its climatic setting is mainly governed by weather systems that originate in the Barents Sea region to the east (Taurisano et al., 2007). These provide the major moisture source for precipitation during the winter season (Førland et al., 1997) with the absolute amounts partly depending on sea-ice coverage (Rogers et al., 2001). During conditions of easterly air flow, Vestfonna is located in the lee of its larger and higher neighbour Austfonna, which leads to precipitation sums being generally smaller (Hagen, 1993).

Snow accumulation throughout the slopes of Vestfonna was found to be mainly governed by terrain elevation (Möller et al., 2011a,b). Along the main ridges the pattern of accumulated winter snow shows substantial zonal variability that differs between individual years (Beaudon et al., 2011). The prevalence of katabatic wind directions throughout the slopes of the ice cap (Claremar et al., 2012) promotes radial drifting snow trajectories while synoptic winds and thus less consistent drifting snow directions dominate on the ridges (Möller, 2012; Möller et al., 2013). Overall, the magnitude of snow accumulation across the ice cap shows high interannual variability and therewith reflects the synoptic forcing (Beaudon et al., 2011).

\section{Field observations}

This study makes use of different types of field data for validation purposes, i.e. snow-depth information from radioecho sounding and snow-pit analysis as well as in situ meteorological measurements at automatic weather stations.

A snow-depth profile that is acquired from radio-echo sounding carried out in spring 2009 by Grabiec et al. (2011) serves as a basis for the validation of the modelled snow accumulation pattern (Fig. 1). The first part of this profile that is used in this study extends over $14 \mathrm{~km}$ and reaches from the forefield of the north-western land-terminating parts of Vestfonna up to the main ridge of the ice cap and further on to the Ahlmann summit. The second used part of the profile covers $32 \mathrm{~km}$ of the western part of the main ridge. The original snow-depth soundings provide point data that are unevenly distributed along the profile line. For its application in model validation we smoothed the original data using a 21-point moving-window filter in order to eliminate local outliers. Afterwards the smoothed profile data were averaged to fit the $250 \mathrm{~m}$ pixel resolution of the modelling domain. Snow depth along the profile ranges between 0 and $2.24 \mathrm{~m}$. According to the measurements, three different types of altitude-dependent accumulation patterns are observable, i.e. inversion, precipitation and redistribution. At elevations below $350 \mathrm{~m}$ the snow accumulates in a permanent aggregation wedge (Grabiec et al., 2011; Ahlmann, 1933) and forms 


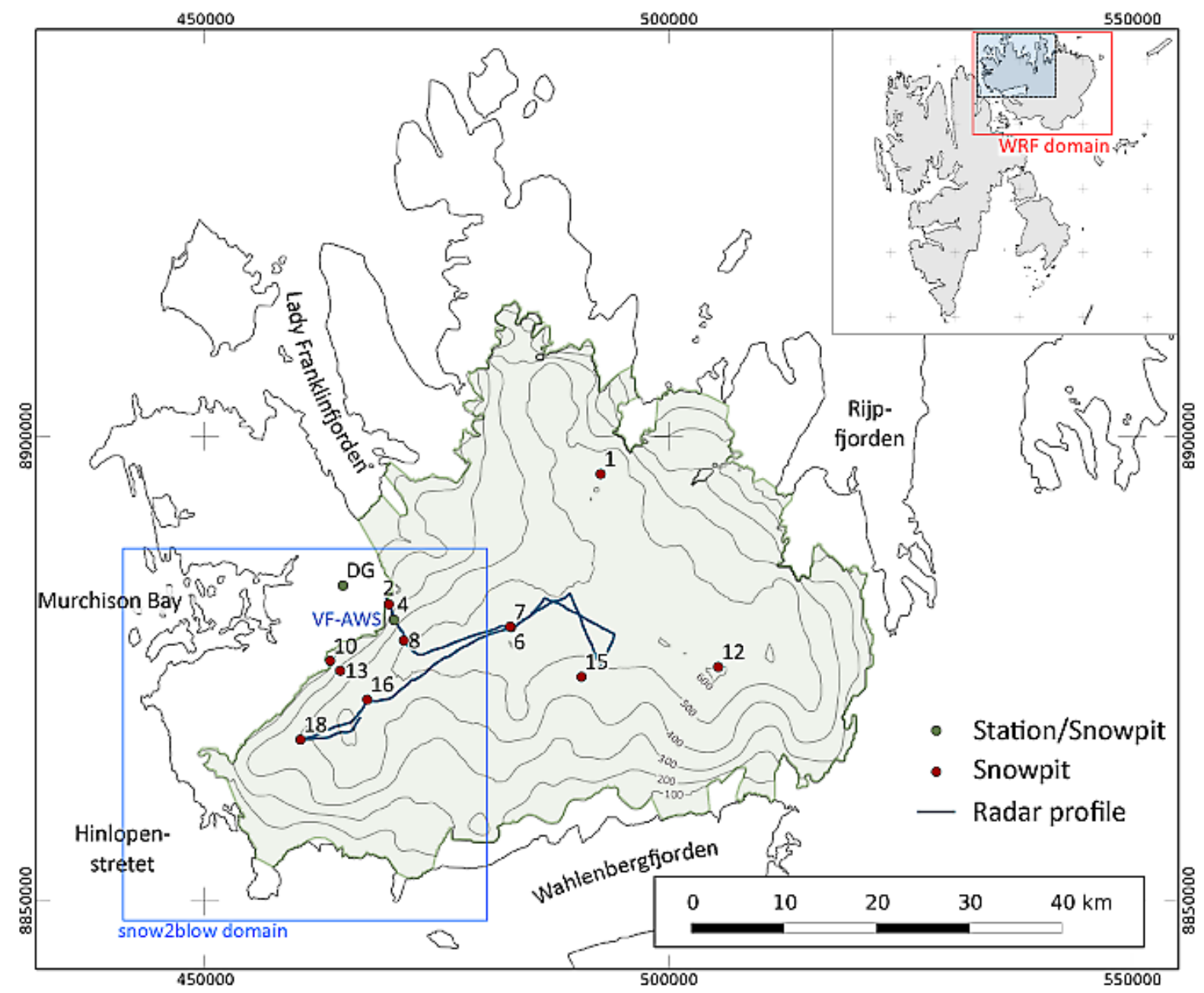

Fig. 1. Detailed map of the Vestfonna ice cap (UTM 34N, WGS84). The grey shading shows the approximate edge of the ice cap. The locations of the automatic weather stations VF-AWS (accompanied by snow-pit measurement) are denoted as green dots, and single snow-pit measurements as red dots. The radio-echo sounding profile of Grabiec et al. (2011) is indicated as a blue line. Contours show the elevations of the ice cap.

a surrounding snow band that is clearly visible on satellite images throughout the entire year. Within a small zone of this snow band snow depth gradually decreases with increasing altitude. In contrast, snow depth above an altitude of $350 \mathrm{~m}$ tends to increase with altitude. Throughout the uppermost parts of the ice cap the spatial distribution of snow depth is mainly determined by snowdrift that results in frequent sastrugi formation and thus in a high local-scale variability of snow accumulation. The radar measurements shown in Figs. 5 and 6 indicate both low and high frequency fluctuations of snow depth that can be attributed to short- and longwave sastrugi formation as it is especially visible between markers D and $\mathrm{E}$.

Point related, multi-year snow-cover data from an extensive snow-pit study (Möller et al., 2011b) provide information on snow depth and density for 21 points on Vestfonna and nearby De Geerfonna for the period 2007-2010. Accord- ing to this study, the mean density of the snowpack lies in the range $300-400 \mathrm{~kg} \mathrm{~m}^{-3}$. The snow-pit data are integrated in the discussion of qualitative model performance with respect to interannual persistence of the ice cap-wide snowdepth pattern.

Meteorological data from an automatic weather station operated on the north-western slope of Vestfonna (VF-AWS, Fig. 1) since spring 2008 are used for validation of Polar Weather Research and Forecast model (PWRF) derived fields of wind speed and direction, air temperature and relative humidity (see Table 4). The records used here comprise the period September 2008 to May 2009. 


\section{Physical processes in two-phase flow}

The redistribution of snow strongly depends on the available turbulent kinetic energy of the atmospheric boundary layer, and thus from the momentum flux and the surface shear effects (Liston and Sturm, 1998; Lehning et al., 2008; Bintanja, 2000). Once the surface shear stress exceeds the inertia and the cohesive bonds of the snow particles, transport takes place. Within a thin surface layer the ejected particles follow a ballistic trajectory under the influence of gravitational force. The rebounds of these particles on the snow surface, again, are able to eject more grains. This near-surface layer is barely influenced by turbulence so that the prevailing particle transport mechanism is pure saltation. Depending on the momentum flux some of the particles within the saltation layer may be entrained further upwards against their gravitational force by turbulent diffusion and further suspended by the mean flow. Once the particle is in suspension the particle velocity is assumed to be equivalent to the fluid velocity.

Blowing and drifting of snow is considered to be a dilute two-phase flow consisting of solid snow particles in a fluid phase. Transport and exchange processes in such two-phase flows are given by turbulent fluid motion, which in turn is affected by the presence of the particles. Thus, snow particles can either enhance or dampen turbulent velocity fluctuations depending on the different characteristic time- and length scales of the flow. It appears that if snow particles are small compared to the turbulent length scale they tend to absorb turbulent kinetic energy (Gore and Crowe, 1989). The evolution of turbulence in the presence of snow particles is a function of the Stokes number $S t$, which is given by the ratio of the particle relaxation time and the characteristic timescale of energy containing eddies (Kolmogorov timescale $\left.\tau=(\nu / \epsilon)^{1 / 2}\right)$. Assuming that the particle diameters of drifting snow are typically in the range $10-400 \mu \mathrm{m}$ and the Kolmogorov length scale of the atmosphere is $(\eta=$ $\left.\left(v^{3} / \epsilon\right)^{1 / 4}\right) \eta \approx 1 \mathrm{~mm}$ leads to a $S t<1$. Such a small Stokes number implies that the particles enhance the dissipation of turbulent energy in order to keep the particles in suspension. This reduces the available turbulent energy for further entrainment.

Elgobashi (1994) likewise described interaction effects of particle-laden flows by $S t$ and the average volumetric particle concentration. Since the average volumetric snow particle concentration of suspended snow is usually below $10^{-3}$ (Bintanja, 2000; Gauer, 2001; Schneiderbauer et al., 2008), and thus the average distance between the particles is large compared to their size, it is feasible to neglect interaction effects (Crowe et al., 1996; Elgobashi, 1994). As shown by Bintanja (2000) the presence of particles also modifies the mean wind velocity profile. Snow particles in suspension are balanced by the particle-fluid drag force and the counteracting gravity force. If this equilibrium is perturbed by turbulent motion the air parcels experience an anomalous buoyancy, which is sim- ilar to a thermally stable turbulent layer. As a consequence of the stable stratification the density of the fluid-particle mixture increases towards the surface. Therefore, friction velocity $u_{*}$ is not constant with height according to $u_{*}=\sqrt{\tau_{0} / \rho}$, leading to a reduction of the turbulent exchange coefficient $K_{M}=\kappa u_{*} z$. Due to the change of the turbulent exchange coefficient, the wind speed gradient and thus the wind speed increase.

\section{Model description}

\subsection{General comments and model set-up}

Snow erosion and transport processes are inherently linked to the characteristics of the air flow and snow properties. Therefore, the quantitative assessment of snow redistribution requires an approximation of the buoyant, turbulent surface wind field. Similar to previous studies (e.g. Liston and Sturm, 1998; Naaim et al., 1998; Schneiderbauer et al., 2008; Bintanja, 2000; Pomeroy and Gray, 1990; Gauer, 2001; Durand et al., 2005), the interactions between particles are neglected and snow particles are treated as a continuous phase solely interacting with the background flow. The proposed model solves the Reynolds averaged Navier-Stokes equation using the $k-\omega$ turbulence model. The model is implemented within the open source $\mathrm{C}++$ library OpenFOAM and is freely downloadable at the author's web page.

\subsection{Governing equations}

The turbulent flow is assumed to be incompressible, so that the continuous continuity equation reduces to

$$
\frac{\partial u_{i}}{\partial x_{i}}=0 \text {. }
$$

Taking the particle buoyancy and Boussinesq approximation into account while neglecting the Coriolis force, the extended momentum equation can be written using Einstein's summation notation as

$$
\begin{aligned}
\frac{\mathrm{d} u_{i}}{\mathrm{~d} t} & =-\frac{1}{\rho} \frac{\partial p}{\partial x_{i}}-\delta_{i 3} g+v_{\mathrm{t}} \frac{\partial^{2} u_{i}}{\partial x_{j}^{2}}-g \delta_{i 3} \frac{\phi_{s}}{\rho} \\
& +\delta_{i 3} g\left[1-\beta\left(\bar{\theta}-\theta_{0}\right)\right],
\end{aligned}
$$

where $x_{i}(\mathrm{i}=1,2,3)$ are the Cartesian coordinates and $u_{i}$ are the Cartesian components of the velocity vector. The fourth term on the right side describes the particle buoyancy. The Boussinesq approximation $g\left[1-\beta\left(\bar{\theta}-\theta_{0}\right)\right]$ considers density changes due to temperature variations in the lower atmosphere and primarily forces the katabatic surface winds. The $\beta\left(1.0 \times 10^{-3} \mathrm{~K}^{-1}\right)$ is the coefficient of thermal expansion. All remaining terms are similar to the common NavierStokes equation (e.g. Stull, 1988). Proceeding from the instantaneous internal energy equation the conservation equation of the potential temperature can be derived, and finally becomes 
Table 1. Notation.

\begin{tabular}{|c|c|}
\hline$e_{\text {Salt }}$ & efficiency of saltation $\left[0 \leq e_{\text {salt }} \leq 1\right]$ \\
\hline$g$ & gravitational acceleration $\left[\mathrm{m} \mathrm{s}^{-2}\right]$ \\
\hline$h_{\text {salt }}$ & saltation layer height $[\mathrm{m}]$ \\
\hline$k$ & turbulent kinetic energy $\left[\mathrm{m}^{2} \mathrm{~s}^{-2}\right]$ \\
\hline$q_{\mathrm{e}}$ & erosion flux $\left[\mathrm{kg} \mathrm{m}^{-2} \mathrm{~s}^{-1}\right]$ \\
\hline$q_{\mathrm{d}}$ & vertical turbulent diffusion flux $\left[\mathrm{kg} \mathrm{m}^{-2} \mathrm{~s}^{-1}\right]$ \\
\hline$q_{\mathrm{s}}$ & horizontal flux in saltation layer $\left[\mathrm{kg} \mathrm{m}^{-2} \mathrm{~s}^{-1}\right]$ \\
\hline$q_{\text {salt }}$ & snow mass flux in the saltation layer $\left[\mathrm{kg} \mathrm{m}^{-2} \mathrm{~s}^{-1}\right]$ \\
\hline$u_{*}$ & friction velocity $\left[\mathrm{m} \mathrm{s}^{-1}\right]$ \\
\hline$u_{\text {salt }}$ & horizontal saltation particle velocity $\left[\mathrm{m} \mathrm{s}^{-1}\right]$ \\
\hline$u_{\mathrm{th}}$ & friction velocity threshold $\left[\mathrm{m} \mathrm{s}^{-1}\right]$ \\
\hline $\bar{w}$ & terminal velocity $\left[\mathrm{m} \mathrm{s}^{-1}\right]$ \\
\hline$z$ & height above surface $[\mathrm{m}]$ \\
\hline $\operatorname{Pr}, P r_{\mathrm{t}}$ & laminar and turbulent Prandtl number [-] \\
\hline$Q_{*}$ & total incident radiation $\left[\mathrm{W} \mathrm{m}^{-2}\right]$ \\
\hline$V$ & mean particle settling velocity $\left[\mathrm{m} \mathrm{s}^{-1}\right]$ \\
\hline$V_{\mathrm{v}}$ & ventilation velocity $\left[\mathrm{m} \mathrm{s}^{-1}\right]$ \\
\hline$\alpha$ & $k-\omega$ model coefficient \\
\hline$\beta_{k}, \beta_{k}^{*}$ & $k-\omega$ model coefficients \\
\hline$\beta$ & coefficient of expansion $\left[\mathrm{K}^{-1}\right]$ \\
\hline$\delta_{i j}$ & Kronecker delta \\
\hline$\theta$ & potential temperature $[\mathrm{K}]$ \\
\hline$\kappa$ & von Kármán constant \\
\hline$\kappa_{\text {eff }}$ & heat transfer coefficient $\left[\mathrm{m}^{2} \mathrm{~s}\right]$ \\
\hline$v$ & kinematic viscosity $\left[\mathrm{m}^{2} \mathrm{~s}\right]$ \\
\hline$v_{\mathrm{t}}$ & turbulent viscosity $\left[\mathrm{m}^{2} \mathrm{~s}\right]$ \\
\hline$\rho_{s}$ & snow density $\left[\mathrm{kg} \mathrm{m}^{-3}\right]$ \\
\hline$\rho$ & air density $\left[\mathrm{kg} \mathrm{m}^{-3}\right]$ \\
\hline$\sigma_{k}^{*}, \sigma_{\omega}^{*}$ & $k-\omega$ model coefficients \\
\hline$\tau_{0}^{\kappa}$ & surface shear stress $\left[\mathrm{kg} \mathrm{m}^{-1} \mathrm{~s}^{-2}\right]$ \\
\hline$\phi_{\mathrm{S}}$ & snow mass in saltation layer $\left[\mathrm{kg} \mathrm{m}^{-3}\right]$ \\
\hline$\phi_{\max }$ & max. particle concentration (steady-state) $\left[\mathrm{kg} \mathrm{m}^{-3}\right]$ \\
\hline$\psi_{\mathrm{s}}, \psi_{t}$ & sublimation-loss-rate coefficients [-] \\
\hline$\omega$ & turbulent dissipation $\left[\mathrm{s}^{-1}\right]$ \\
\hline
\end{tabular}

$\frac{\partial \bar{\theta}}{\partial t}+\frac{\partial\left(\bar{\theta} u_{i}\right)}{\partial x_{i}}-\frac{\partial}{\partial x_{j}}\left(\kappa_{\mathrm{eff}} \frac{\partial \bar{\theta}}{\partial x_{j}}\right)=0$

whereas temperature changes by radiative forcing and phase change of water are neglected in this study. The heat transfer coefficient $\kappa_{\text {eff }}$ is a function of the laminar and turbulent Prandtl number, $P r_{1}$ and $P r_{t}$, given as

$\kappa_{\mathrm{eff}}=\frac{\nu_{\mathrm{t}}}{P r_{\mathrm{t}}}+\frac{v}{P r}$.

The Reynolds averaged momentum equation is closed using the $k-\omega$ turbulence model. The equation for the turbulent kinetic energy, $k$, reads as

$$
\frac{\partial k}{\partial t}+\frac{\partial u_{j} k}{\partial x_{j}}=P_{k}+B_{k}-\beta_{k}^{*} k \omega+\frac{\partial}{\partial x_{j}}\left[\left(v+\frac{v_{\mathrm{t}}}{\sigma_{k}^{*}}\right) \frac{\partial \omega}{\partial x_{j}}\right],
$$

Table 2. Coefficients used for the $k-\omega$ turbulence model (values are adopted from Ferziger and Perić, 1996).

$\alpha=\frac{5}{9} \quad \beta=0.075 \quad \beta^{*}=0.09 \quad \sigma_{k}^{*}=\sigma_{\omega}^{*}=2 \quad \epsilon=\beta^{*} \omega k$

with the production rate of kinetic energy by the shear $P_{k}$ and buoyancy $B_{k}$ estimated by

$P_{k}=v_{\mathrm{t}}\left(\frac{\partial u_{i}}{\partial x_{j}}+\frac{\partial u_{j}}{\partial x_{i}}\right) \frac{\partial u_{i}}{\partial x_{j}}$

and

$B_{k}=\frac{v_{\mathrm{t}}}{P r_{\mathrm{t}}} \beta_{k} g \frac{\partial T}{\partial z}$.

The equation for dissipation uses the inverse timescale $\omega$ that determines the scale of turbulence:

$$
\frac{\partial \omega}{\partial t}+\frac{\partial u_{j} \omega}{\partial x_{j}}=\alpha \frac{\omega}{k} P_{k}+B_{\omega}-\beta_{k} \omega^{2}+\frac{\partial}{\partial x_{j}}\left[\left(v+\frac{v_{\mathrm{t}}}{\sigma_{\omega}^{*}}\right) \frac{\partial \omega}{\partial x_{j}}\right],
$$

with the corresponding buoyancy term $B_{\omega}$, given as

$B_{\omega}=\frac{\omega}{k}(\alpha+1)\left(\max \left(B_{k}, 0\right)-B_{k}\right)$.

The buoyancy production terms $B_{k}$ and $B_{\omega}$ consider the thermal stratification of the atmospheric flow and can be source or sink terms. Based on these equations the turbulent viscosity is defined as

$v_{\mathrm{t}}=\frac{k}{\omega}$.

The various empirical constants are given in Table 2. In the current model structure the enhanced dissipation of turbulent kinetic energy by snow particles is neglected, even though this effect is present.

The rate of snow mass change $\partial \phi_{\mathrm{s}} / \partial t$ is described by the continuum equation for conservation of mass:

$\underbrace{\frac{\partial \phi_{\mathrm{s}}}{\partial t}}_{\text {(I) }}+\underbrace{\frac{\partial\left(\phi_{\mathrm{s}} u_{i}\right)}{\partial x_{i}}}_{\text {(II) }}=\underbrace{\frac{\partial}{\partial x_{3}}\left(v_{\mathrm{t}} \frac{\partial \phi_{\mathrm{s}}}{\partial x_{3}}-V \phi\right)}_{\text {(III) }}+\underbrace{\left(\frac{\partial \phi_{\mathrm{s}}}{\partial t}\right)_{\mathrm{sub}}}_{\text {(IV) }}$.

Since we make the simplifying assumption that the relative velocity between the two phases is always zero there is no need to use a combined phase continuity equation as it reduces to the equivalent single phase flow equation. This approach considers snow particles solely as a passive tracer with a constant total density of the air-snow mixture. Particularly within the lower region of the surface layer this leads to a slight underestimation of the mass flux. Assuming a snow drift density of $0.2 \mathrm{~kg} \mathrm{~m}^{-3}$ the error would be less than $7 \%$. The drifting snow flux in the $i$ direction is $\phi_{\mathrm{s}} u_{i}$ and therefore the net flux due to the fluid motion is given by the divergence of the mass flux (term II). Term IV gives the mass loss 
Table 3. Model parameters.

\begin{tabular}{llllll}
\hline Parameter & Symbol & Value & Unit & Reference & Comments \\
\hline Erosion efficiency & $e_{\mathrm{salt}}$ & $5 \times 10^{-4}$ & - & Naaim et al. (1998) & \\
Fallout velocity & $V$ & 0.2 & $\mathrm{~m} \mathrm{~s}^{-1}$ & Bintanja (2002) & assuming a mean particle radius of 60 $\mu \mathrm{m}$ \\
Fresh snow density & $\rho_{\mathrm{s}}$ & 200 & $\mathrm{~kg} \mathrm{~m}^{-3}$ & Benn and Evans (2010) & very dense freshly fallen snow \\
Density of ice & $\rho_{i}$ & 900 & $\mathrm{~kg} \mathrm{~m}^{-3}$ & Bintanja (2001) & \\
Snow particle albedo & $\alpha_{\mathrm{p}}$ & 0.1 & - & Déry et al. (1998) & \\
Laminar Prandtl number & $P r$ & 0.7 & - & \\
Turbulent Prandtl number & $P r_{\mathrm{t}}$ & 0.9 & - & \\
Kinematic viscosity & $v$ & $1.73 \times 10^{-5}$ & $\mathrm{~m}^{2} \mathrm{~s}^{-1}$ & & \\
\hline
\end{tabular}

of suspended snow by sublimation. Besides the vertical entrainment of snow particles by turbulent diffusion, there is a downward flux $-V \phi$ due to gravity (term III). For the sake of simplicity the terminal fallout velocity $V$ is assumed to be constant (see Table 3). The total amount of drifting and blowing snow mass depends on the erosion flux and accumulation flux, respectively, which are discussed in detail in the next section.

\subsection{Erosion and accumulation flux}

The snow mass within the saltation layer primarily gains by the aerodynamic entrainment of snow particles from the underlying snowpack. According to Anderson and Haff (1991) the erosional mass flux $q_{\mathrm{e}}$ is assumed to be proportional to the excess surface shear stress,

$q_{\mathrm{e}}=e_{\mathrm{salt}}\left(\rho u_{*}^{2}-\rho_{\mathrm{a}} u_{\mathrm{th}}^{2}\right)$.

Once the surface shear stress $u_{*}^{2}$ exceeds the friction threshold velocity $u_{\text {th }}$ particles are ejected from the snowpack. The efficiency of the erosional process is described by the $e_{\text {salt }}$. The friction threshold velocity strongly depends on the physical properties of the snowpack. Through the process of kinetic and melt-freeze metamorphosis the snowpack is in a constant state of change. Both processes modify the snow density and hence the kinetic resistance of the snowpack. The friction threshold velocity is therefore assumed to be proportional to the snow density (Walter et al., 2004),

$u_{\mathrm{th}}=0.0195+\left(0.021 \sqrt{\rho_{\mathrm{s}}}\right)$.

Typical values for $u_{\mathrm{th}}$ are in the range of $0.3 \mathrm{~m} \mathrm{~s}^{-1}$ for loose fresh snow to $0.6 \mathrm{~m} \mathrm{~s}^{-1}$ for consolidated firn. Based on these values saltation starts at wind speed $u_{10}$ of about $7-14 \mathrm{~m} \mathrm{~s}^{-1}$ for consolidated snow and of about $4-11 \mathrm{~m} \mathrm{~s}^{-1}$ for fresh snow (cf. Pomeroy and Gray, 1990). However, the ejected particles do have a strong impact on the prevailing flow which affects the mass exchange process. The force exerted by the particles on the wind field lowers the wind shear stress and consequently reduces the capacity to eject further particles. To allow for such effect the friction velocity is corrected by the particle-saturation ratio (Naaim et al., 1998).
Taking into account the particle-saturation ratio the corrected friction velocity $u_{*}^{\text {corr }}$ can be written as

$u_{*}^{\text {corr }}=u_{*}+\left(u_{\mathrm{th}}-u_{*}\right)\left(\frac{\phi_{\mathrm{s}}}{\phi_{\max }}\right)^{2}$.

If the drifting snow density reaches saturation $\phi_{\max }$, the friction velocity reduces to the friction threshold velocity and entrainment is suppressed. In case the saltation layer contains no particles the corrected and uncorrected friction velocities are equal. The maximum concentration $\phi_{\max }$ is estimated by the following semi-empirical relationship (Pomeroy and Male, 1992),

$\phi_{\max }=\frac{\rho}{3.29 u_{*}}\left(1-\frac{u_{\mathrm{th}}^{2}}{u_{*}^{2}}\right)$.

By replacing $u_{*}$ by $u_{*}^{\text {corr }}$ in Eq. (12), the final erosion flux,

$q_{\mathrm{e}}=e_{\mathrm{salt}}\left(\rho\left[\left(u_{\mathrm{th}}-u_{*}\right)\left(\frac{\phi_{\mathrm{s}}}{\phi_{\max }}\right)^{2}+u_{*}\right]^{2}-\rho u_{\mathrm{th}}^{2}\right)$,

is obtained. Once the threshold velocity exceeds the friction velocity deposition is possible. Similar to Beyers et al. (2004) the deposition flux is simply related to the downward flux (Eq. 11) and the shear stress ratio.

$q_{\mathrm{d}}=V \phi \cdot \max \left(\frac{u_{\mathrm{th}}^{2}-u_{*}^{2}}{u_{\mathrm{th}}^{2}}, 0\right)$

\subsection{Sublimation}

The approximation of the sublimation-loss rates of suspended snow follows that of Liston and Sturm (1998), Schmidt (1972, 1991), Pomeroy and Gray (1995), Pomeroy et al. (1993), Bintanja (2000) and Naaim et al. (1998) and is given as

$q_{\mathrm{s}}=\int_{h_{*}}^{z} \psi_{t}(z) \phi_{t}(z) \mathrm{d} z$ 
The sublimation-loss-rate coefficients $\psi_{\mathrm{s}}$ represent the time rate of change of snow particle mass as a function of the mean particle size $\bar{m}(z)$, so that

$\psi_{t}(z)=\frac{\frac{\mathrm{d} \bar{m}(z)}{\mathrm{d} t}}{\bar{m}(z)}$,

and

$\bar{m}(z)=\frac{4}{3} \pi \rho_{i} \bar{r}(z)^{3}$.

The change in mass,

$$
\frac{\mathrm{d} \bar{m}}{\mathrm{~d} t}=\frac{2 \pi \bar{r} \sigma-\frac{Q_{r}}{K N u T_{\mathrm{a}}}\left[\frac{L_{\mathrm{s}}}{R_{\mathrm{v}} T_{\mathrm{a}}}-1\right]}{\frac{L_{\mathrm{s}}}{K N u T_{\mathrm{a}}}\left[\frac{L_{\mathrm{s}}}{R_{\mathrm{v}} T_{\mathrm{a}}}-1\right]+R_{\mathrm{v}} \frac{T_{\mathrm{a}}}{\operatorname{Sh} D e_{i}}},
$$

is controlled by the rate at which water vapour is removed from the snow particle and the available amount of thermal energy, where $\sigma$ is the water vapour deficit with respect to ice, $T_{\mathrm{a}}$ the environmental air temperature, $K$ the thermal conductivity of air $\left(0.024 \mathrm{~W} \mathrm{~m}^{-1} \mathrm{~K}^{-1}\right), L_{\mathrm{S}}$ the latent heat of sublimation $\left(2.838 \times 10^{6} \mathrm{~J} \mathrm{~kg}^{-1}\right), R_{\mathrm{V}}$ the gas constant for water vapour $\left(461.5 \mathrm{~J} \mathrm{~kg}^{-1} \mathrm{~K}^{-1}\right.$ ), and $D$ the molecular diffusivity of water vapour in air $\left(2.25 \times 10^{-5} \mathrm{~m}^{2} \mathrm{~s}^{-1}\right)$. The mean radius of snow particles $\bar{r}$ vary with height as:

$\bar{r}(z)=4.6 \times 10^{-5} z^{-0.258}$.

The heat and mass transfer at the particle surface is described by the dimensionless Nusselt number $N u$ and Sherwood number $S h$, defined as

$N u=S h=1.79+0.606 \operatorname{Re}(z)^{0.5}$,

with $R e$ being the particle Reynolds number:

$\operatorname{Re}(z)=\frac{2 \bar{r} V_{\mathrm{v}}(z)}{v}$,

where $v$ is the kinematic viscosity of air and $V_{\mathrm{v}}$ the ventilation velocity, which is assumed to be equal to the particle size dependent terminal velocity. Following Pomeroy and Male (1992) we estimate the terminal velocity $\bar{w}$ as

$\bar{w}(z)=1.1 \times 10^{7} \bar{r}(z)^{1.8}$.

The net radiation absorbed by the particles $Q_{\mathrm{r}}$ is described by

$Q_{\mathrm{r}}=\pi r^{2}\left(1-\alpha_{\mathrm{p}}\right) Q_{*}$,

where $\alpha_{\mathrm{p}}$ represents the shortwave particle albedo, assumed to be 0.1 , and $Q_{*}$ the total incident radiation.

The effect of sublimation on the vertical profiles of temperature and humidity is not included in this work, since the near-surface atmosphere is mostly saturated and will probably contribute only a minor fraction to the surface mass balance (see Table 4). This simplified assumption ignores the fact that sublimation of drifting snow is a self-limiting process, in the sense that the intensity depends on the saturation deficit of the environment. Neglecting the feedback mechanism on the atmospheric profiles can therefore lead to an overestimation of snow drift sublimation.

\subsection{Discretization}

The domain is subdivided into a finite number of small control volumes, and fluxes are approximated by surface and volume integrals. The model is integrated forward in time using an implicit Euler scheme with adaptive time stepping. All convection terms are implicitly solved and discretized using an upwind differencing scheme for stability reasons. The Laplacian terms, in turn, are discretized by central differencing. The set of partial differential equations are solved using the PISO (pressure implicit with splitting operators) algorithm to enforce mass conservation at each time step (see Ferziger and Perić, 1996). At each time step wind velocity and temperature are predicted using the pressure from the previous iteration. Usually, the wind velocities do not satisfy the continuity equation at this time and the wind velocities need to be corrected. The correction procedure modifies the pressure field by solving the Poisson equation. At this point the continuity equation is satisfied, but the velocity and pressure do not satisfy the momentum equation. Therefore, the correction process is iterated until the velocity field satisfies both the momentum and continuity equations.

Boundary conditions at all boundaries must be given in order to solve the equations. If no cyclic conditions are used, the vertical profiles for wind (speed and direction), blowing snow density, temperature and turbulent kinetic energy must be provided at the inlets. The erosion and accumulation flux at the surface boundary are implemented as boundary condition for the continuity equation of snow mass. The sublimation flux is calculated after the field correction is carried out and the snow continuity equation has been solved.

\section{Ideal case study}

\subsection{Initial and boundary conditions}

In the following an ideal test case is set up to demonstrate the model behaviour. In order to compare the results with other models, a similar set-up to that proposed by Xiao et al. (2000) is chosen. To drive the atmospheric boundary layer flow an initial near-surface logarithmic wind profile is provided with a friction velocity $u_{*}=0.87 \mathrm{~m} \mathrm{~s}^{-1}$ and a roughness length $z_{0}=0.001 \mathrm{~m}$. The atmospheric boundary layer is neutrally stratified having a constant potential temperature $\theta=253.16 \mathrm{~K}$ up to $300 \mathrm{~m}$. Above $300 \mathrm{~m}$, temperature gradually increases with a vertical temperature gradient of $0.005 \mathrm{~K} \mathrm{~m}^{-1}$ providing a capping inversion. The pressure field is initialized according the hypsometric equation, 


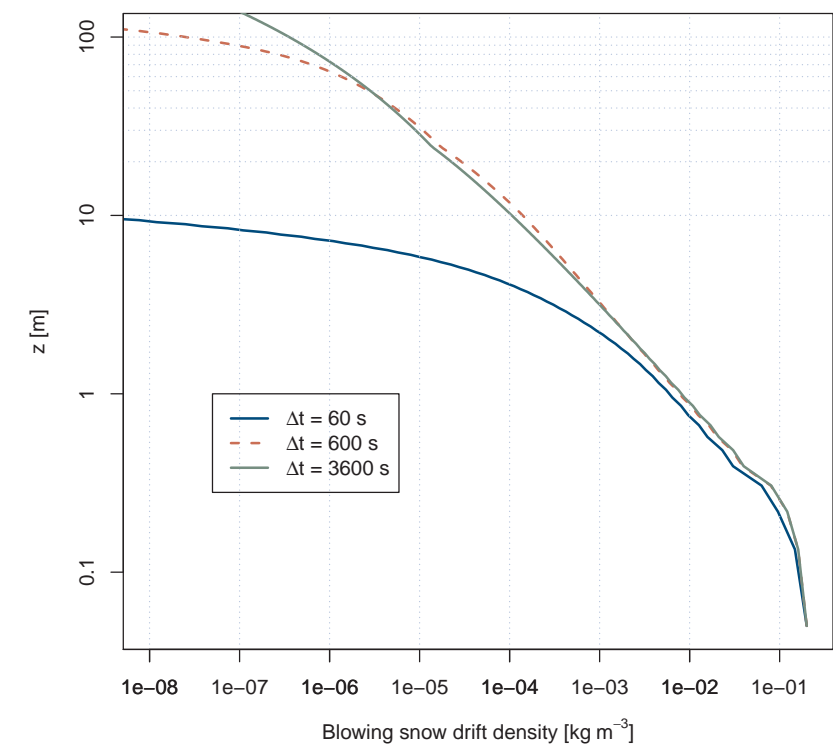

Fig. 2. Profiles of blowing snowdrift density predicted after $\Delta t=60$, 600 and $3600 \mathrm{~s}$ for the ideal case study.

$p=p_{0} \exp \left(-\frac{z g}{R_{\mathrm{d}} \theta_{0}}\right)$,

where the surface pressure $p_{0}$ is assumed to be $1000 \mathrm{hPa}$ and $R_{\mathrm{d}}$ is the gas constant for dry air $\left(287 \mathrm{~J} \mathrm{~kg}^{-1} \mathrm{~K}^{-1}\right)$. The relative humidity profile decreases linearly from $100 \%$ at the surface to $70 \%$ at $100 \mathrm{~m}$. Above that level relative humidity is kept constant. For the ideal case simulation the particle drift density at the lower boundary is set to a constant value of $0.2 \mathrm{~kg} \mathrm{~m}^{-3}$.

Cyclic lateral boundary conditions are used in both horizontal directions, while a stress free condition is used at the top. The domain height is set to $1000 \mathrm{~m}$ in order to avoid that mass is transferred across the top boundary. The horizontal grid spacing is $100 \mathrm{~m}$. The grid consists of 150 vertical layers gradually increasing from the surface to the top with a constant cell ratio of 1.25 . Using this ratio the first cell centre is located at $0.11 \mathrm{~m}$.

\subsection{Model results}

Figure 2 shows the evolution of the vertical snow drift density profile at $t=60,600$ and $3600 \mathrm{~s}$. It is evident, that snow particles are efficiently entrained further upwards by the turbulent eddies. In the lower atmospheric boundary layer $(z<5 \mathrm{~m})$ the turbulent diffusion and particle settling are already balanced after $600 \mathrm{~s}$. Snowdrift density varies little with height in the near-surface region $(z<0.2 \mathrm{~m})$, but slightly exceeds the densities simulated by PIETUK, WINDBLAST and SNOWSTORM (Xiao et al., 2000). However, above this level snowdrift density decreases at a quicker rate. Thus the resulting vertical snow drift density profile is not as

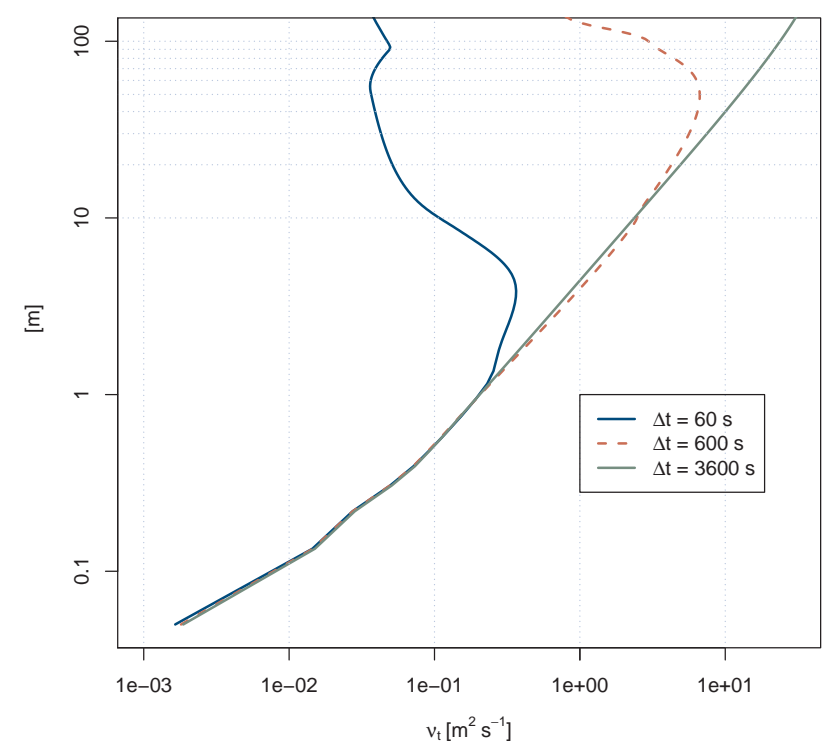

Fig. 3. Evolution of the turbulent viscosity profiles for the ideal case study.

steep as those presented by Xiao et al. (2000). The characteristic timescale of the entrainment process, and therefore the vertical distribution of the particle density is related to the turbulent viscosity $v_{\mathrm{t}}$ (see Fig. 3).

The local sublimation rates are shown in Fig. 4. At the surface the sublimation rate is zero, since the relative humidity is set to $100 \%$. Despite the small saturation deficit near the ground, sublimation rates show a clear maximum which is a consequence of the large number of particles. The cooling and moistening of air due to the sublimation process reduces the sublimation rates (Bintanja, 2000; Déry et al., 1998; Xiao et al., 2000). For the moment the thermodynamic feedback of sublimation on the boundary layer is not included in the snow2blow model and local sublimation rates are constant in time. The vertical integrated sublimation rate in the suspension layer is about $0.58 \mathrm{~mm} \mathrm{~h}^{-1}$. This rate is 1.8 times as high as the sublimation rates simulated by Déry et al. (1998) for the same $10 \mathrm{~m}$ nominal wind speed. Consequently, the model overestimates the sublimation rates and attention must be given when interpreting the sublimation results.

\section{Vestfonna Ice Cap}

\subsection{Numerical set-up}

The snow2blow model is applied to the south-western part of Vestfonna $\left(79^{\circ} 41^{\prime} 49.029^{\prime \prime}\right.$ to $80^{\circ} 04^{\prime} 09.647^{\prime \prime} \mathrm{N}$, $18^{\circ} 12^{\prime} 33.253^{\prime \prime}$ to $19^{\circ} 58^{\prime} 17.844^{\prime \prime} \mathrm{E}$ ) with a horizontal resolution of $250 \mathrm{~m}$. For this study the domain top is set to $3000 \mathrm{~m}$, consisting of 5 vertical layers in the near-surface layer $(5 \mathrm{~m})$ and further 40 vertical layers above. The vertical layer height gradually increases with a constant cell expansion ratio of 
Table 4. Mean monthly temperature and relative humidity with respect to ice at the automatic weather stations De Geerfonna and VF-AWS. Two measurements at different heights $(2.1$ and $3.9 \mathrm{~m})$ are given for the AWS Vestfonna. Temperature and relative humidity at the AWS De Geerfonna is measured at a height of $1.9 \mathrm{~m}$.

\begin{tabular}{|c|c|c|c|c|c|c|c|c|c|}
\hline \multirow{4}{*}{$\begin{array}{l}\bar{T}\left[{ }^{\circ} \mathrm{C}\right] \\
\overline{\mathrm{RH}}[\%]\end{array}$} & \multicolumn{9}{|c|}{ De Geerfonna } \\
\hline & Sep & Oct & Nov & Dec & Jan & Feb & Mar & Apr & May \\
\hline & -1.1 & -10.3 & -13.7 & -13.2 & -18.4 & -17.4 & -17.6 & -23.4 & -6.0 \\
\hline & 96.2 & 100.0 & 100.0 & 100.0 & 93.5 & 100.0 & 100.0 & 100.0 & 93.9 \\
\hline & \multicolumn{9}{|c|}{ Vestfonna } \\
\hline & Sep & Oct & Nov & Dec & Jan & Feb & Mar & Apr & May \\
\hline $\bar{T}\left[{ }^{\circ} \mathrm{C}\right]$ & $-2.1 /-2.1$ & $-11.3 /-11.2$ & $-14.5 /-14.1$ & $-14.0 /-13.8$ & $-18.8 /-18.4$ & $-18.2 /-17.8$ & $-17.7 /-17.3$ & $-20.7 /-20.5$ & $-8.4 /-8.1$ \\
\hline
\end{tabular}

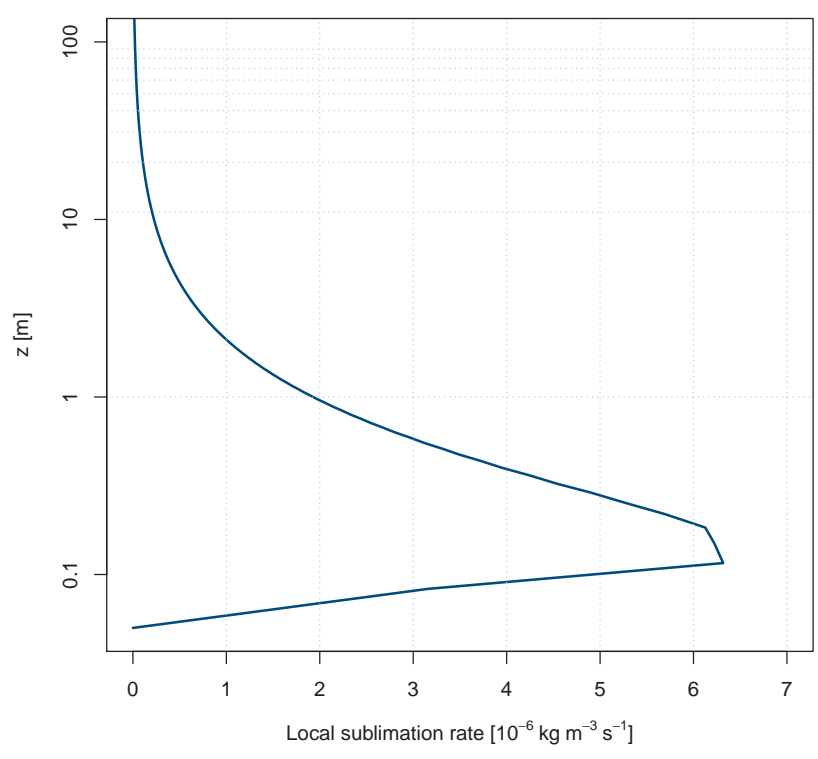

Fig. 4. Vertical profile of the local sublimation rate in the suspension layer.

1.25. This set-up allows for a better representation of the turbulent near-surface wind field and the derived fluxes therefrom. The decision to highly resolve the surface layer was drawn at the expense of the horizontal domain size, because any additional vertical layer increases the computational cost exponentially. The daily atmospheric fields from PWRF with a horizontal resolution of $2 \mathrm{~km}$ are mapped onto the snow2blow grid. It is then forced by the lateral boundaries of the PWRF, so that an independent internal turbulent wind field can evolve. The snow mass flux at the boundaries for the saltation layer is given by the formulation of Pomeroy and Gray (1990):

$q_{\mathrm{salt}}=\frac{0.68 \rho}{u_{*} g} u_{\mathrm{th}}\left(u_{*}^{2}-u_{\mathrm{th}}^{2}\right)$.

The inflow snow density profile for the suspension layer is given by Pomeroy and Male (1992):

$\phi_{\mathrm{S}}\left(u_{*}, z\right)=0.8 \cdot \exp \left[-1.55\left(4.784 u_{*}^{-0.544}-z^{-0.544}\right)\right]$.
Up to now, no parameterization scheme for the snow cover evolution is included, which might account for the snow densification processes. However, in order to prevent that the entire snow cover is eroded at once only the present day fresh snow is allowed to redistribute. This is an acceptable assumption given the fact that the high wind velocities lead to a rapid densification of the upper snow cover (Möller et al., 2011b) and formation of sastrugi. Snowdrift model parameters used for the simulations are given in Table 3 .

Weather conditions in the study region are homogenized and downscaled to 1 day temporal and $2 \mathrm{~km}$ spatial resolution on the basis of weather observations and the polaroptimized PWRF. The regional reanalysis from the PWRF is based on the six-hourly Global Forecast System (GSF) global gridded analysis of the National Centers for Environmental Prediction (NCEP) with a spatial resolution of $1.0^{\circ}$. Lateral boundary conditions for the downscaling are given by NCEP low resolution real-time global sea surface temperature analysis (NCEP RTG SST) with a spatial resolution of $0.5^{\circ}$ and Advanced Microwave Scanning Radiometer-EOS (AMSR-E) daily sea-ice concentrations with a spatial resolution of $12.5 \mathrm{~km}$. The static geographical fields of the PWRF model are initialized using the United States Geological Survey (USGS) standard datasets. The applied downscaling procedure features a telescope two-way nesting of three polar stereographic domains (30, 10 and $2 \mathrm{~km}$ horizontal resolution). The inner domain of this nesting is used as input to the snow2blow model. All three domains are resolved in 28 vertical layers reaching up to the $50 \mathrm{hPa}$ level. The temporal reprocessing from the original six-hourly to the final daily datasets is done using the method presented by Maussion et al. (2011). The set-up of the physical parameterizations of the PWRF model is motivated by Hines et al. (2011) and Hines and Bromwich (2008).

\subsection{PWRF model evaluation}

The performance of the PWRF generated atmospheric fields was evaluated with data from the VF-AWS. Figure 7 shows the observed wind conditions at the VF-AWS and the closest PWRF grid point, respectively. Frequent strong winds of 


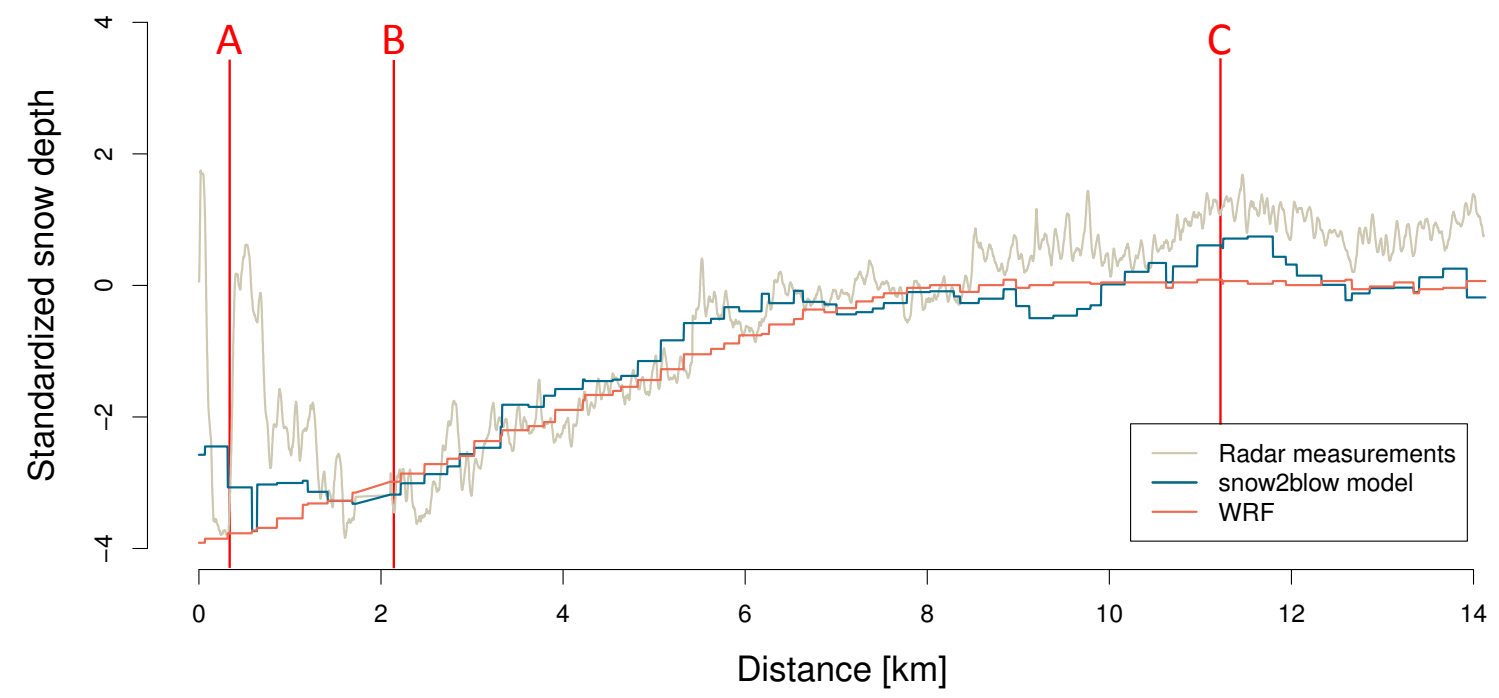

Fig. 5. The standardized anomalies (by subtracting the sample mean, and dividing by the sample standard deviation) of the radio-echo sounding, modelled snow depths and solid precipitation as resolved by the regional reanalysis (PWRF) along the profile shown in Fig. 1. Capital letters correspond to the markers given in Fig. 9.

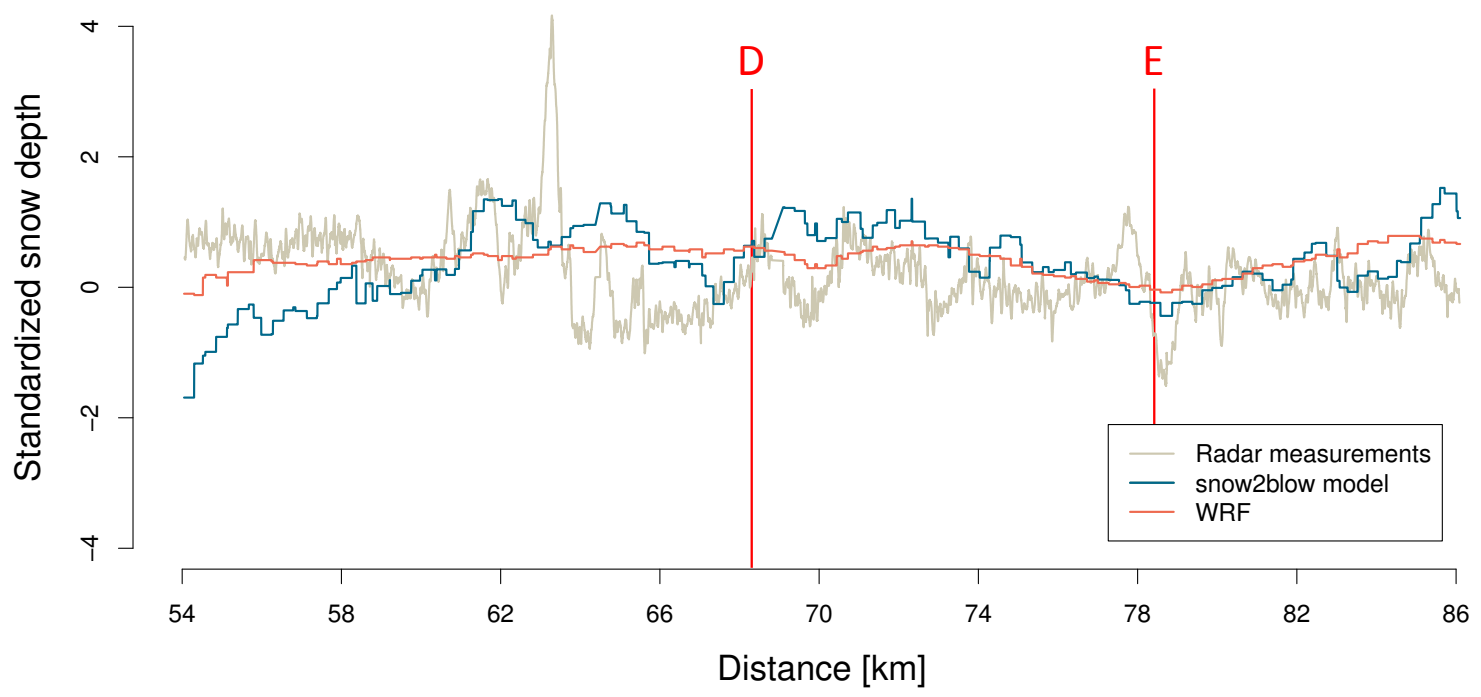

Fig. 6. The standardized anomalies (by subtracting the sample mean, and dividing by the sample standard deviation) of the radio-echo sounding, modelled snow depths and PWRF along the profile shown in Fig. 1. Note that the mean SWEs of the radio-sounding, snow2blow model and PWRF model are approximately 0.34, 0.47 and $0.56 \mathrm{~m}$. Capital letters correspond to the markers given in Fig. 9.

up to $15 \mathrm{~m} \mathrm{~s}^{-1}$ are observed from the south-easterly direction, clearly indicating the persistent katabatic wind flows. In contrast, the more fluctuating north-westerly flows are weak during the entire observation period. For validation the best out of the four closest PWRF model grid points was chosen and compared with the observations (Claremar et al., 2012). The PWRF wind speed at $10 \mathrm{~m}$ height was corrected to the corresponding sensor height at $2.4 \mathrm{~m}$ using the Monin-Obukhov theory for stable boundary layer (Stull, 1988), while the Obukhov length has been derived from the PWRF output variables. The model slightly overestimates the katabatic wind speeds and tends to have a more southerly wind component (Fig. 7). Air temperatures at $2 \mathrm{~m}$ height varied at the VF-AWS between -37.9 and $+5.8^{\circ} \mathrm{C}$ during this period. Observed and modelled air temperatures significantly correlate with an $r^{2}=0.98$, but show a neglectable cold bias of $-0.05 \mathrm{~K}$, which is a problem of the PWRF model that was previously reported for the study region (Claremar et al., 2012).

Figure 8 shows the spatial distribution of the uncorrected snow water equivalent (SWE) field for the accumulation period September 2008 to May 2009 obtained from the PWRF 


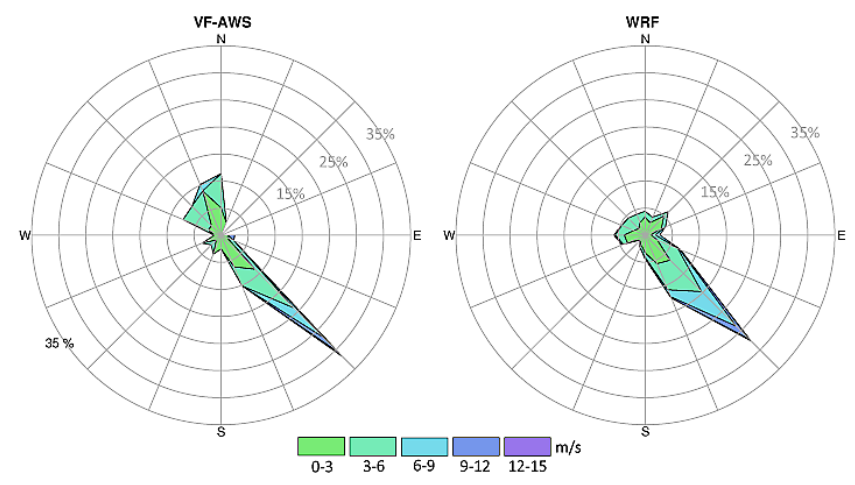

Fig. 7. Wind direction and speed measured at the VF-AWS (left) and modelled by the PWRF (right).

model run. Snow distribution is predominantly controlled by altitude ranging from $0.2 \mathrm{~m}$ w.e. (water equivalent) in coastal areas to $0.6 \mathrm{~m}$ w.e. in higher regions along the ridge of the ice cap. The general increase of SWE with altitude is consistent with studies carried out by Grabiec et al. (2011) and Möller et al. (2011b). However, these studies also emphasize that drifting and blowing snow often lead to local-scale deviation from this dominant pattern.

\subsection{Discussion on snowdrift}

The modelled distribution of SWE on the Vestfonna ice cap for the period September 2008 to May 2009 is shown in Fig. 9. Snow is heterogeneously distributed across the domain ranging between $0.11 \mathrm{~m}$ w.e. in the south-east and $0.49 \mathrm{~m}$ w.e. in higher regions. This corresponds to a total snow loss of $\sim 10-20 \%$ along the ridge by blowing snow. At the ice cap slopes the total snow loss is about $5-15 \%$. Parts of the eroded and suspended snow mass is later accumulated in the undulating north-western forefield of the ice cap. In regions of disturbed flow, re-accumulation can be more than $0.1 \mathrm{~m}$ w.e. for the accumulation period 2008/2009. In this way, the De Geerfonna ice body receives between 15 and $20 \%$ of its total snow mass by drifting snow, which therefore is an important term for the local mass balance. Snow mass blowing away from the ice cap to the open sea was not quantified in this study. Jaedicke (2002) estimated that snow mass loss to the open sea only accounts for $0.2 \%$ of the precipitated mass in Svalbard. In most areas near the ice fringe and the western forefield accumulation and erosion are widely balanced. In contrary, the largest snow mass losses of 0.10 $0.25 \mathrm{~m}$ w.e. $(30-50 \%)$ are found in the south-east of the main ridge. A comparison of modelled snow depths with radioecho soundings and snow pits shows that there is a bias of $+0.07 \mathrm{~m}$ w.e. along the ridge, while at the De Geerfonna snow is underestimated by about $-0.08 \mathrm{~m}$ w.e. by the model (see Table 5). However, these errors are insignificant in the light of the spatial variability of snow water equivalent, which sometimes may vary between $\pm 0.13 \mathrm{~m}$ w.e. within very short

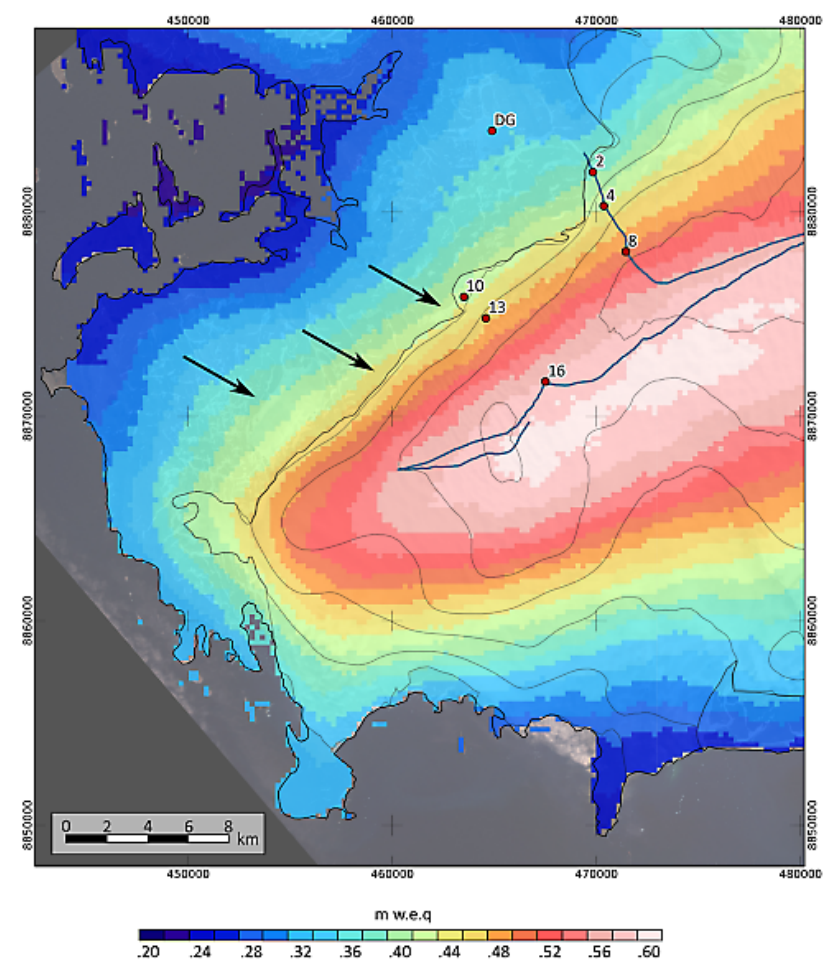

Fig. 8. Snow accumulation in $m$ w.e. from the PWRF model runs over the period September 2008 to May 2009. The arrows mark regions of special interest which are discussed in detail in the text. The locations of snow-pit measurements are denoted as red dots (location labelling is adapted from Möller et al. (2011b)). The blue line shows the radio-echo sounding profile of Grabiec et al. (2011) in May 2009.

distances of less than $50 \mathrm{~m}$ caused by sastrugi formation. Due to the limited information on the spatial distribution, it remains uncertain whether the deviations represent a systematic pattern or are purely random. Particularly at the slopes, the snow2blow has difficulties reproducing the variability of the snow distribution (see Table 5). The low variability indicates that there is not enough snow eroded and redistributed in this zone.

The occurrence of drifting and blowing snow events follow a pattern similar to the SWE distribution (see Fig. 10). Blowing and drifting of snow occur most frequently (38-40\%) at wind-exposed regions, such as the higher elevated regions along the ridge. In the realm of the isolated upstream ice bodies (including De Geerfonna) and the ice cap slopes 30 $34 \%$ of snow erosion occurs. Lower frequencies (20-24\%) are generally found in the forefield of the ice cap and on the south-eastern slope. This might be one of the reasons why the model does not erode enough snow in this area. These patterns imply that drifting snow events are triggered by the superposition of the paramount flow and katabatic winds, whereas the katabatic component is less efficient. This result is similar to observations of Grabiec et al. (2011), who 
Table 5. Standard deviation and mean of the snow water equivalent $[\mathrm{m}]$ of the radar-echo sounding measurements, snow $2 \mathrm{blow}$ model and $\mathrm{PWRF}$ at the slopes and the ridge, respectively. The measured snow water equivalent at De Geerfonna ( $\left.\mathrm{SWE}_{\mathrm{DG}}\right)$ is based on snow-pit data.

\begin{tabular}{lccccc}
\hline & SWE $_{\text {DG }}$ & $\overline{\text { SWE }_{\text {slope }}}$ & $\sigma_{\text {SWE }}($ slope $)$ & $\overline{\text { SWE }_{\text {ridge }}}$ & $\sigma_{\text {SWE }}$ (ridge) \\
\hline Measurements & 0.48 & 0.29 & 0.10 & 0.34 & 0.04 \\
snow2blow model & 0.40 & 0.34 & 0.05 & 0.39 & 0.01 \\
PWRF & 0.34 & 0.49 & 0.06 & 0.56 & 0.01 \\
\hline
\end{tabular}
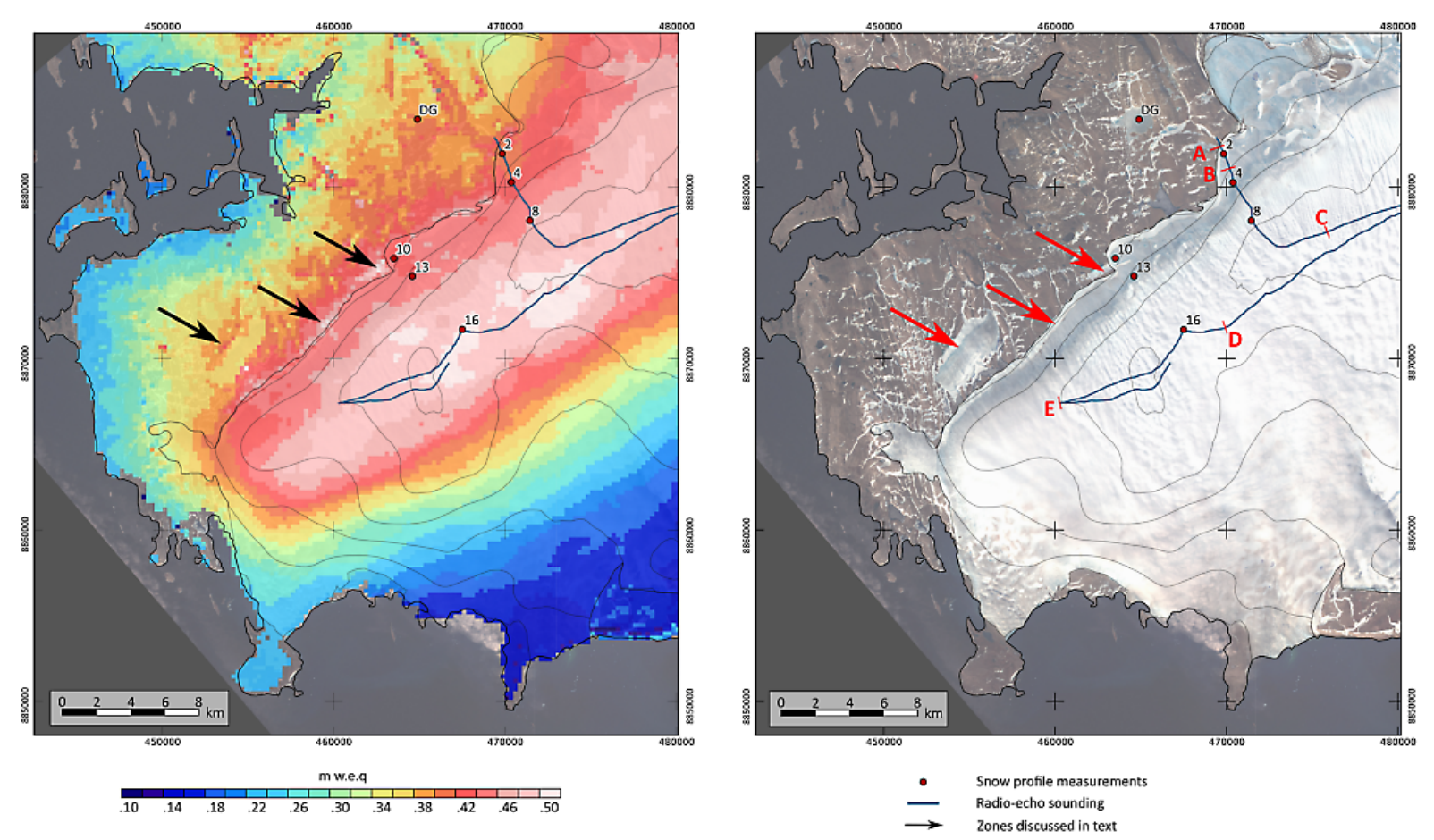

Fig. 9. Modelled snow depths in m w.e. after the accumulation season 2008/2009 (left) and ASTER satellite image from 17 August 2000 (right, UTM 34N, WGS84). The arrows mark regions of special interest which are discussed in detail in the text. The locations of snowpit measurements are denoted as red dots (location labelling is adapted from Möller et al. (2011b)). The blue line shows the path of the radio-echo sounding measurements in May 2009.

found that air circulation patterns over Nordaustlandet and the mesoscale surface roughness play a major role in snow redistribution on the interior of Vestfonna. The magnitude of the modelled katabatic wind component along the slopes varies between $1-2 \mathrm{~m} \mathrm{~s}^{-1}$ at $2 \mathrm{~m}$ height during the winter months, and thus leading to $u_{*} \leq 0.1 \mathrm{~m} \mathrm{~s}^{-1}$. The glacier wind components may be underestimated as a consequence of the assumption of homogeneous surface temperatures, which affects the buoyancy term and subsequently the occurrence of drifting snow events at the slopes.

Indeed it is observed that katabatic glacier winds redistribute snow from the slopes to the ice edge forming a persistent surrounding snow band (see arrows in Fig. 9). Since the snow band exists all year, it is very likely that more accumulation takes place at these zones or less snow is eroded. Although katabatic winds might be underestimated, the distribution of the snow band along the Vestfonna margin and the nearby Backabreen and De Geerfona are clearly reproduced by the snowdrift model. Together with the radar-echo sounding (Figs. 5, 9) it appears that after the $2-3 \mathrm{~km}$ wide snow band SWE on the ice cap slopes decreases rapidly within a short distance of $2 \mathrm{~km}$ (marker B in Figs. 9 and 5). This decrease in SWE with altitude in the vicinity of the ice edge is also observed in most years by the snow-pit measurements at location V2 and V4 (Möller et al., 2011b). The general spatial distribution along the slopes and the higher regions is reproduced by the model, as indicated in Fig. 5. Discrepancies are found in the region of the snow band and in the section between kilometre 54 and 58 along the radarecho sounding path. The former one is most likely due to the limitations of the $250 \mathrm{~m}$ grid cell resolution in reproducing the complex small-scale topography and its curvature pattern along the ice cap margin. Furthermore, the sudden change in mesoscale terrain roughness at the glacier fringe increases 


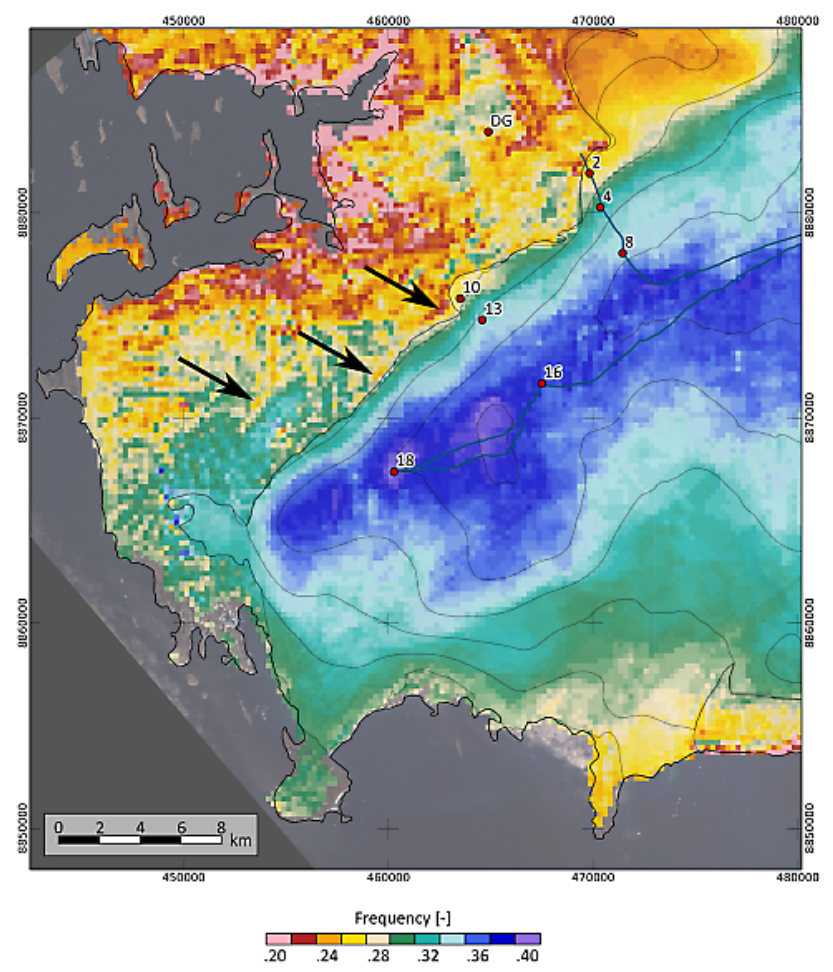

Fig. 10. Drifting snow frequency in the period September 2008 to May 2009, defined as the ratio of days with non-zero erosion flux and the total number of days. The locations of snow-pit measurements are denoted as red dots (location labelling is adapted from Möller et al. (2011b)). The blue line shows the radio-echo sounding profile of Grabiec et al. (2011) in May 2009.

the turbulent kinetic energy and decreases the vertical wind shear. This process weakens the katabatic wind at the glacier slope, and thus the suspension capacity of the flow. Snow accumulated by this process is not captured by the model. To account for this process a large eddy simulation model is required, rather than a Reynolds averaged model, in order to resolve the small-scale flow pattern in detail. The overestimation of erosion between kilometre 54 and 58, however, can be probably attributed to boundary effects.

For the sake of clarity, drifting snow sublimation is discussed for the location VF-AWS, and has been integrated over the lower atmospheric boundary layer $(10 \mathrm{~m})$. Since no vertical moisture measurements are available, the vertical profile of the undersaturation $\sigma$ is given by (Liston and Sturm, 1998; Dery and Taylor, 1996)

$\sigma(z)=\sigma_{\mathrm{rH}}(\Gamma-0.027 \ln (z))$,

where $\sigma_{\mathrm{rH}}$ is the undersaturation measured at the sensor height $z_{\mathrm{rH}}$, and $\Gamma$ is the relative humidity offset described by

$\Gamma=1-0.027 \ln \left(z_{\mathrm{rH}}\right)$.

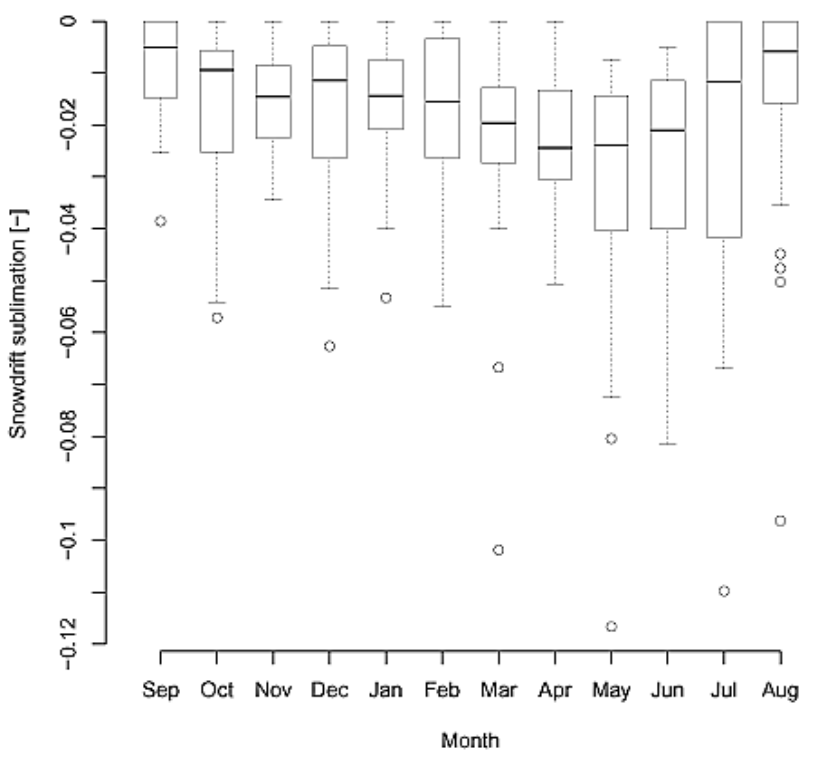

Fig. 11. Interseasonal variability of the mean snowdrift sublimation within the near-surface layer (below $10 \mathrm{~m}$ ) at the location VF-AWS for the period 2008/2009. The boxes spread between lower and upper quartiles of the values with the median shown as the thick line in between, the whiskers extend the boxes by 1.5 times the interquartile range. Values outside this range are considered as outliers.

Drifting and blowing snow sublimation shows a seasonal cycle with average sublimation rates between 2-3\% in April/May (see Fig. 11). During the winter months 1-2\% of the total suspended snow is sublimated. The seasonal variability can be attributed to the interplay between saturation deficit, temperature and wind speed. Particularly in spring, conditions are favourable when high saturation deficits occur simultaneously with strong winds and moderate temperatures. As mentioned in Sect. 6.2, sublimation rates could be overestimated due to the missing feedback mechanism in the snow2blow model. Given that the air mass near the surface is very moist during the winter time, we argue that the error is relatively small compared to other uncertainties.

\section{Conclusions}

This paper presents a high-resolution $(250 \mathrm{~m})$ spatial estimation of snowdrift over the Vestfonna ice cap during the accumulation season 2008/2009. Blowing and drifting snow are frequent processes (10-25\%) which significantly modify snow accumulation distribution of the entire ice cap. In particular, along the wind exposed zones about $10-20 \%$ of the primarily accumulated snow is redistributed to peripheral zones and must be considered a loss term for the ice cap mass balance. In this way, ice bodies such as the De Geerfonna receive up to $20 \%$ additional snow mass. Based on the results, three characteristic erosion zones can be identified on Vestfonna ice cap: (1) inversion zone, decrease of SWE with 
altitude; (2) precipitation zone, increase of SWE similar to the precipitation gradient; and (3) redistribution zone, where the spatial distribution of snow is characterized by blowing and drifting of snow triggered by the paramount flow. These zones correspond to snow radar observations of Grabiec et al. (2011). Whether blowing snow from sea-ice surfaces provide additional snow mass is still an open question. There is a pronounced variation in drifting and blowing snow sublimation during the simulation period with a maximum in April/May with mean sublimation rates of $2-3 \%$, and a minimum in winter with mean rates between $1-2 \%$. These rates could be overestimated by the model and must treated with caution. A detailed analysis of the effect of drifting snow sublimation on surface sublimation was not performed in this study, but will be covered in the future.

Further work will also include drifting and blowing snow processes into the calculation of glacier mass balance and a more detailed description of snowpack processes. In general the snow2blow model captures the spatial snowdrift pattern, but underestimates the erosion at the ice cap slopes. In this context more work has to be done on the simulation of the small-scale wind field. The available data do not allow a rigorous validation of the model and the results. Obviously the validity of the model must be confirmed and proven in the future by comparing the outcomes with high-resolution data.

Acknowledgements. This study was co-funded by grants no. BR 2105/6-1, SCHE 750/3-1 and SCHN 680/2-1 of the German Research Foundation (DFG). The Polish Ministry of Science and Higher Education funded the radar field work with grant no. IPY/279/2006. Additional funding was provided by the International SvalGlac-Project of the European Science Foundation through the German Federal Ministry of Education and Research (BMBF, grants no. 03F0623A and 03F0623B) and NCBiR/PolarCLIMATE-2009/2-1/2010. The authors acknowledge the logistical assistance of the Swedish Polar Research Secretariat in the field that was provided in the framework of the 3rd International Polar Year (IPY) core project IPY Kinnvika, and of the Norsk Polar Institute for provision of logistical support at the Oxford Halfoya field camp. We thank both S. Déry and J. Lenaerts for their detailed comments and constructive criticism of the original manuscript.

Edited by: M. Van den Broeke

\section{References}

Ahlmann, H.: Scientific results of the Swedish-Norwegian Arctic Expedition in the summer of 1931. Part VIII, Geogr. Ann., 15, 161-216, 1933.

Anderson, R. and Haff, P.: Wind modification and bed response during saltation of sand in air, Acta Mech., 1, 21-52, supplementum 1. Aoelian Grain Transport. 1: Mechanics, 1991.

Beaudon, E., Arppe, L., Jonsell, U., Martma, T., Möller, M., Pohjola, V., Scherer, D., and Moore, J.: Spatial and temporal variability of net accumulation from shallow cores from Vestfonna ice cap (Nordaustlandet, Svalbard), Geogr. Ann., 93, 287-299, 2011.

Bednorz, E. and Fortuniak, K.: The occurrence of coreless winters in central Spitsbergen and their synoptic conditions, Polar Res., 30, 2011.

Benn, D. I. and Evans, D. J.: Glaciers and glaciation, Hodder Education, 2010.

Beyers, J., Sundsbø, P., and Harms, T.: Numerical simulation of three-dimensional, transient snow drifting around a cube, J. Wind Eng. Ind. Aerod., 92, 725-747, 2004.

Bintanja, R.: The contribution of snowdrift sublimation to the surface mass balance of Antarctica, Ann. Glaciol., 27, 251-259, 1998.

Bintanja, R.: Snowdrift suspension and atmospheric turbulence. Part I: Theoretical background and model description, Bound.Lay. Meteorol., 95, 343-368, 2000.

Bintanja, R.: Snowdrift sublimation in a katabatic wind region of the Antarctic ice sheet, J. Appl. Meteorol., 40, 1952-1966, 2001.

Bintanja, R.: A new power-law relation for the vertical distribution of suspended matter, Bound.-Lay. Meteorol., 104, 305-317, 2002.

Boon, S., Burgess, D., Koerner, R., and Sharp, M.: Forty-seven Years of Research on the Devon Island Ice Cap, Arctic Canada, Arctic, 13-29, 2010.

Braun, M., Pohjola, V., Pettersson, R., Möller, M., Finkelnburg, R., Falk, U., Scherer, D., and Schneider, C.: Changes of glacier frontal positions of Vestfonna (Nordaustlandet, Svalbard), Geogr. Ann., 93, 301-310, 2011.

Claremar, B., Obleitner, F., Reijmer, C., Pohjola, V., Waxegård, A., Karner, F., and Rutgersson, A.: Applying a Mesoscale Atmospheric Model to Svalbard Glaciers, Adv. Meteorol., 2012, 321649, doi:10.1155/2012/321649, 2012.

Crowe, C., Troutt, T., and Chung, J.: Numerical models for twophase turbulent flows, Annu. Rev. Fluid Mech., 28, 11-43, 1996.

Déry, S., Taylor, P. A., and Xiao, J.: The Thermodynamic Effects of Sublimating, Blowing Snow in the Atmospheric Boundary Layer, Bound.-Lay. Meteorol., 89, 251-283, doi:10.1023/A:1001712111718, 1998.

Dery, S. J. and Taylor, P. A.: Some aspects of the interaction of blowing snow with the atmospheric boundary-layer, Hydrol. Process., 10, 1345-1358, 1996.

Durand, Y., Gyomarc'h, G., Mérindol, L., and Corripio, J.: Improvement of a numerical snow drift model and field validation, Cold Reg. Sci. Technol., 43, 93-103, 2005.

Elgobashi, S.: On predicting particle-laden turbulent flows, Appl. Sci. Res., 52, 309-329, 1994.

Ferziger, J. H. and Perić, M.: Computational methods for fluid dynamics, vol. 3, Springer Berlin, 1996.

Førland, E., Hanssen-Bauer, I., and Nordli, P.: Climate statistics and longterm series of temperature and precipitation at Svalbard and Jan Mayen, Det Norske Meteorologiske Institutt Klima Report, 21, 97, 1997.

Gauer, P.: Numerical modeling of blowing and drifting snow in Alpine terrain, J. Glaciol., 47, 97-110, 2001.

Gore, R. and Crowe, C.: Effect of particle size on modulating turbulent intensity, Int. J. Multiphas. Flow, 15, 278-285, 1989.

Grabiec, M., Puczko, D., Budzik, T., and Gajek, G.: Snow distribution patterns on Svalbard glaciers derived from radio-echo soundings, Pol. Polar Res., 32, 393-421, 2011. 
Hagen, J.: Glacier atlas of Svalbard and Jan Mayen, 129, Norsk polarinstitutt, 1993.

Hines, K. and Bromwich, D.: Development and Testing of Polar Weather Research and Forecasting (WRF) Model. Part I: Greenland Ice Sheet Meteorology*, Mon. Weather Rev., 136, 19711989, 2008.

Hines, K., Bromwich, D., Bai, L., Barlage, M., and Slater, A.: Development and Testing of Polar WRF. Part III: Arctic Land*, J. Climate, 24, 26-48, 2011.

Jaedicke, C.: Snow drift losses from an Arctic catchment on Spitsbergen: an additional process in the water balance, Cold Reg. Sci. Technol., 34, 1-10, 2002.

Käsmacher, O. and Schneider, C.: An objective circulation pattern classification for the region of Svalbard, Geogr. Ann. A, 93, 259$271,2011$.

Lehning, M., Löwe, H., Ryser, M., and Raderschall, N.: Inhomogeneous precipitation distribution and snow transport in steep terrain, Water Resour. Res., 44, 2008.

Lenaerts, J. T. M., van den Broeke, M. R., Déry, S. J., KönigLanglo, G., Ettema, J., and Munneke, P. K.: Modelling snowdrift sublimation on an Antarctic ice shelf, The Cryosphere, 4, 179190, doi:10.5194/tc-4-179-2010, 2010.

Lenaerts, J. T. M., van den Broeke, M. R., van Angelen, J. H., van Meijgaard, E., and Déry, S. J.: Drifting snow climate of the Greenland ice sheet: a study with a regional climate model, The Cryosphere, 6, 891-899, doi:10.5194/tc-6-891-2012, 2012.

Liston, G. and Sturm, M.: A snow-transport model for complex terrain, J. Glaciol., 44, 498-516, 1998.

Loeng, H.: Features of the physical oceanographic conditions of the Barents Sea, Polar Res., 10, 5-18, 1991.

Maussion, F., Scherer, D., Finkelnburg, R., Richters, J., Yang, W., and Yao, T.: WRF simulation of a precipitation event over the Tibetan Plateau, China - an assessment using remote sensing and ground observations, Hydrol. Earth Syst. Sci., 15, 1795-1817, doi:10.5194/hess-15-1795-2011, 2011.

Mernild, S., Liston, G., Hasholt, B., and Knudsen, N.: Snow distribution and melt modeling for Mittivakkat Glacier, Ammassalik Island, southeast Greenland, J. Hydrometeorol., 7, 808-824, 2006.

Möller, M.: A minimal, statistical model for the surface albedo of Vestfonna ice cap, Svalbard, The Cryosphere, 6, 1049-1061, doi:10.5194/tc-6-1049-2012, 2012.

Möller, M., Finkelnburg, R., Braun, M., Hock, R., Jonsell, U., Pohjola, V., Scherer, D., and Schneider, C.: Climatic mass balance of Vestfonna ice cap, Svalbard: A spatially distributed assessment using ERA-Interim and MODIS data, J. Geophys. Res., 116, F03009, doi:10.1029/2010JF001905, 2011a.

Möller, M., Möller, R., Beaudon, E., Mattila, O.-P., Finkelnburg, R., Braun, M., Grabiec, M., Jonsell, U., Luks, B., Puczko, D., Scherer, D., and Schneider, C.: Snowpack characteristics of Vestfonna and DeGeerfonna (Nordaustlandet, Svalbard) - a spatiotemporal analysis based on multiyear snow-pit data, Geogr. Ann., 93, 273-285, 2011b.

Möller, M., Finkelnburg, R., Braun, M., Scherer, D., and Schneider, C.: Variability of the climatic mass balance of Vestfonna ice cap (northeastern Svalbard), 1979-2011, Ann. Glaciol., 54, 63, doi:10.3189/2013AoG63A407, 2013.
Naaim, M., Naaim-Bouvet, F., and Martinez, H.: Numerical simulation of drifting snow: erosion and deposition models, Ann. Glaciol., 26, 191-196, 1998.

Pomeroy, J. and Gray, D.: Saltation of Snow, Water Resour. Res., 26, 1583-1594, 1990.

Pomeroy, J. and Gray, D.: Snowcover accumulation, relocation and management, Bulletin of the International Society of Soil Science no, 88, 1995.

Pomeroy, J. and Male, D.: Steady-state suspension of snow, J. Hydrol., 136, 275-301, 1992.

Pomeroy, J., Gray, D., and Landine, P.: The prairie blowing snow model: characteristics, validation, operation, J. Hydrol., 144, 165-192, 1993.

Rogers, A., Bromwich, D., Sinclair, E., and Cullather, R.: The Atmospheric Hydrologic Cycle over the Arctic Basin from Reanalyses. Part II: Interannual Variability*, J. Climate, 14, 2414-2429, 2001.

Schmidt, R.: Sublimation of Wind-transported Snow: A Model, Rocky Mountain Forest and Range Experiment Station, Forest Service, US Department of Agriculture, 1972.

Schmidt, R.: Sublimation of snow intercepted by an artificial conifer, Agr. Forest Meteorol., 54, 1-27, 1991.

Schneiderbauer, S., Tschachler, T., Fischbacher, J., Hinterberger, W., and Fischer, P.: Computational fluid dynamic (CFD) simulation of snowdrift in alpine environments, including a local weather model, for operational avalanche warning, Ann. Glaciol., 48, 150-158, 2008.

Schytt, V.: Scientific Results of the Swedish Glaciological Expedition to Nordaustlandet, Spitsbergen, Geogr. Ann., 46, 242-281, 1964.

Skeie, P.: Meridional flow variability over the Nordic seas in the, Geophys. Res. Lett., 27, 2569-2572, 2000.

Stull, R.: An introduction to boundary layer meteorology, vol. 13, Springer, 1988.

Svendsen, H., Beszczynska-Møller, A., Hagen, J., Lefauconnier, B., Tverberg, V., Gerland, S., Ørbæk, J., Bischof, K., Papucci, C., Zajaczkowski, M., Azzolini, R., Bruland, O., Wiencke, C., Winther, J.-G., and Dallmann, W.: The physical environment of Kongsfjorden-Krossfjorden, an Arctic fjord system in Svalbard, Polar Res., 21, 133-166, 2002.

Taurisano, A., Schuler, T., Hagen, J., Eiken, T., Loe, E., Melvold, K., and Kohler, J.: The distribution of snow accumulation across the Austfonna ice cap, Svalbard: direct measurements and modelling, Polar Res., 26, 7-13, 2007.

Walczowski, W. and Piechura, J.: Influence of the West Spitsbergen Current on the local climate, Int. J. Climatol., 31, 1088-1093, 2011.

Walter, M. T., McCool, D. K., King, L. G., Molnau, M., and Campbell, G. S.: Simple snowdrift model for distributed hydrological modeling, J. Hydrol. Eng., 9, 280-287, 2004.

Xiao, J., Bintanja, R., Déry, S., Mann, G., and Taylor, P.: An intercomparison among four models of blowing snow, Bound.-Lay. Meteorol., 97, 109-135, 2000. 